\title{
Soil fertility management for groundnut in the lowveld of Mpumalanga and north coastal plain of KwaZulu-Natal provinces of South Africa
}

Zharare, G.E. ${ }^{1}$ and Vilane, N.M. ${ }^{2}$

Correspondence author: G. E. Zharare. Email zharareg@ unizulu.ac.za

\begin{abstract}
Smallholder groundnut production contributes substantially to food security in Mpumalanga Lowveld (MLV) and in Manguzi, the northern coastal plain (NCP) of KwaZulu Natal (KZN), both of which are dominated by infertile structureless sandy soils. A study was conducted to obtain information on the chemical properties of the soils to guide fertilizer management for optimizing groundnut production on these soils. Soil samples were collected from representative sites in $M L V$ and $\mathrm{NCP}$, and analysed for $\mathrm{pH}$, calcium (Ca), magnesium $(\mathrm{Mg})$, potassium $(K)$, phosphorous $(P)$, zinc $(\mathrm{Zn})$ and manganese $(\mathrm{Mn})$ in the peg-zone $(0-10 \mathrm{~cm}$ depth), root zone (10-40 cm depth) and subsoil (40-60 cm depth). The soils were largely acidic, with $\mathrm{pH}$ mostly falling below 5.5. The basic cation concentrations were generally low, and so were $\mathrm{Zn}$ and Mn concentrations. Nonetheless, with the exception of $P$ and $M n$, the soil concentrations of the other nutrients analysed were within ranges considered adequate for vegetative and reproductive growth of groundnut, though Zn was marginally so. General fertility management recommendations to inform agricultural extension are provided for groundnut production on the sandy soils based on the chemical analyses of the soils.
\end{abstract}

Keywords: Groundnut, soil chemical properties, soil fertility management, Lowveld of Mpumalanga, KwaZulu-Natal coastal plain

\section{INTRODUCTION}

Groundnut is the second most important crop grown by smallholder farmers in the Lowveld of Mpumalanga (Ncube et al., 2010) and in Manguzi on the NCP of KwaZulu-Natal (Phokane et $a l ., 2019)$, where it plays an important role in food security and alleviation of protein-energy malnutrition as a functional food (Arya, Salve \& Chauhan, 2016). The soils in Manguzi (Grundling 2011) and MLV (Mathews, 2010) are typically deep structureless sands. Whilst the soils are ideal for groundnut production on account of the ease with which the groundnut gynophores penetrate the soil to form pods, as well as the ease with which the pods can be harvested from the soil (Swanevelder, 1998), they are generally of low fertility, and therefore, highly susceptible to acidity due to their high leachability. Hence, crop production on them usually requires liming and fertilizer inputs. Currently, there is scanty information on the

\footnotetext{
${ }^{1}$ Head of Department, Department of Agriculture, University of Zululand, Private Bag X1001, KwaDlangezwa, 3886, KwaZulu-Natal South Africa. Email: zharareg@unizulu.ac.za.

2 Department of Agriculture, Rural Development Land and Environmental Affairs, Private Bag X 11318 Nelspruit 1200.
} 
general chemical properties of the soils in MLV and the coastal plain of KwaZulu Natal to guide fertilizer management for the smallholder groundnut farmers in the absence of soil analysis. In this study, a soil chemical analysis was carried out for selected representative sites of sandy soils in MLV and Manguzi with the aim of assessing their nutrient status in relation to meeting the nutritional requirements for groundnut. The results of the study provide a basis for fertilizing the groundnut crop in the absence of a soil test.

\section{DESCRIPTION OF THE STUDY AREAS}

The climate of the area surveyed in MLV has warm to hot, moist to wet summers with dry, mild to cool winters. The average annual rainfall ranges from 600 to $800 \mathrm{~mm}$, with $83 \%$ of the falls in the summer growing season from October to March (Paterson, 2012). The temperature varies from 18 to $35{ }^{\circ} \mathrm{C}$ during the summer season (Janila et al., 2013) and from 10 to $25{ }^{\circ} \mathrm{C}$ during winter (Paterson, 2012). The soils are structureless sandy loam (8\% clay), and typically deep (900-1200 mm) and classified as Avalon series (Lengwati et al., 2020).

The climate of Manguzi in the northernmost part of the NCP of KZN is subtropical and receives summer rainfall, with a 30-year mean annual precipitation of approximately 580-963 mm (Mucina \& Rutherford 2006; Matthews, 2007; Ramjeawon et al., 2020). The majority of the rainfall $(60 \%)$ occurs during the summer months, between October and March, and is highly spatially and temporally variable (Ramjeawon et al., 2020). Mean daily temperatures vary from $21.0{ }^{\circ} \mathrm{C}$ to $32.1{ }^{\circ} \mathrm{C}$ in summer and $10.9{ }^{\circ} \mathrm{C}$ to $26.4{ }^{\circ} \mathrm{C}$ in winter (Ramjeawon et al., 2020). The soils majorly consist of deep Aeolian sands (Matthews, 2007).

\section{MATERIALS AND METHODS}

\subsection{Soil sampling sites}

Five and six sites, not less than $2 \mathrm{~km}$ apart, were sampled in MLV and Manguzi, respectively. The five sites in MLV were Lowveld Agricultural College farm (LVAF) -25.440278, 30.982500, Malekutu (-25.369167, 31.271667), Numbi -25.148889, 31.183611, Luphisa 25.436944, 30.973056 and Masoyi -25.159722, 31.158889]. In Manguzi, the six sites were KwaMazambane (-26.930017, 32.781462), Ekuhluphekeni -26.965920, 32.765527, Thandizwe (-26.975483, 32.723929), Nsukumbili -27.035640, 32.697573, Ndlondlweni (27.143905, 32.552688) and Mabhudu (-27.213716, 32.548059). The sites in Manguzi were representative of the sandy soil in the northern (Maputaland) coastal area of KwaZulu-Natal.

\subsection{Soil sampling and processing}

At each of the pit sites, four holes were randomly sampled 10 meters apart. In recognition of separate nutrient requirements in the root and peg-zone of groundnut (Zharare, Blamey \& Asher, 2009; Zharare, Asher \& Blamey, 2011), three soil samples were obtained per sampling hole at depths 0-10 cm (peg-zone), 10-40 cm (root-zone) and 40-60 cm (subsoil) using an auger. 
The soils from the three depths were mixed separately in buckets at each of the pit sites, and a composite soil sample of each of the sampling depth was taken for chemical analysis.

The soil samples were air-dried at room temperature, crushed between rubber belts on a soil crusher, and passed through a $1 \mathrm{~mm}$ sieve. Those materials that could not be crushed were discarded.

\subsection{Determination of $\mathbf{p H}$ and mineral nutrient concentrations}

The chemical analyses included the $\mathrm{pH}$, macronutrients calcium $(\mathrm{Ca})$, magnesium $(\mathrm{Mg})$, potassium (K), phosphorous $(\mathrm{P})$ and micronutrients manganese $(\mathrm{Mn})$ and zink $(\mathrm{Zn})$. The soil $\mathrm{pH}$ was measured in $1 \mathrm{M} \mathrm{KCl}$ in a soil solution ratio of 1:1.25 following a standard procedure described by Pansu and Gautheyrou (2006). The macro- and micronutrients were extracted from $2.5 \mathrm{~g}$ of each $\mathrm{ml}$ sample in $25 \mathrm{ml}$ of Mehlich 3 solution (Mehlich 1984). The resultant suspension was stirred at 400 r.p.m. for $10 \mathrm{~min}$ on a stirrer and filtered using Whatman No.1 paper. Five $\mathrm{ml}$ of the filtrate was diluted with $20 \mathrm{~mL}$ of $0.0356 \mathrm{M} \mathrm{SrCl}_{2}$, and the concentrations of $\mathrm{Ca}$ and $\mathrm{Mg}$ in the filtrate were determined by atomic absorption spectrometry (AAS). Potassium concentration was determined by AAS from $5 \mathrm{~mL}$ of the filtrate after dilution with $20 \mathrm{~mL}$ de-ionised water. Phosphorus concentration was determined from $2 \mathrm{ml}$ of the filtrate using a molybdenum blue procedure as modified by (Hunter, 1974). The micro-nutrients Zn, $\mathrm{Cu}$ and $\mathrm{Mn}$ were determined by AAS from the undiluted filtrate.

\section{RESULTS AND DISCUSSION}

Generally, the soils in MLV and Manguzi were strongly acidic (Table 1). With the exception of Luphisa in MLV, which had soil $\mathrm{pH}$ above 6.0, the $\mathrm{pH}$ values in the peg zone, the root zone in the subsoil at all other sites were less than 5.5, the lower limit in the $\mathrm{pH}$ range 5.5-6.5 considered optimal for groundnut (Kumar et al., 2019). The soils, therefore, require liming to raise the $\mathrm{pH}$ to between 5.5. and 6.5. Lower $\mathrm{pH}$ values adversely affect groundnut root growth and the uptake of $\mathrm{P}$ and boron (B), as well as causing Al toxicity (Fageria and Zimmermann 1998). In addition, low $\mathrm{pH}$ in the peg-zone adversely affects pod development and filling (Murata, Zharare \& Hammes, 2013), as well as nodulation and nitrogen fixation processes (Maccio, Fabra \& Castro, 2002). To raise the $\mathrm{pH}$ from 4.5 to 6.5 in a depth of $30 \mathrm{~cm}$ in sandy

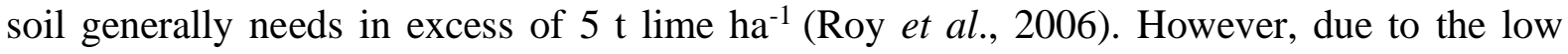
exchange capacity of the soil, and hence poor buffering capacity to $\mathrm{pH}$ changes, liming done at any one time should not exceed $500 \mathrm{~kg} \mathrm{ha}^{-1}$ on sandy soil. High rates of lime can precipitate trace elements such as $\mathrm{Mn}, \mathrm{Zn}$ and iron $(\mathrm{Fe})$, making them unavailable to plants (Fageria \& Zimmermann, 1998). In the absence of a soil test, groundnut production in the soils at MPL (topsoil $\mathrm{pH}$ range 4.3 to 6.2) and Manguzi (topsoil $\mathrm{pH}$ range 4.8 to 5.1) would benefit from splitting lime application of between $900 \mathrm{~kg}$ and $1.5 \mathrm{t} \mathrm{ha}^{-1}$ at 3 to 6 month before planting for a period of up to 3 years. It should also be taken into cognisance that Mupangwa and Tagwitra (2005) determined from a multi-location field study that the optimum calcitic lime application rate on granitic sandy soils in Zimbabwe is $200 \mathrm{~kg} \mathrm{ha}^{-1}$. This was adequate to counteract soil acidity and to supply the Ca needed in the peg zone for proper groundnut fructification and pod filling. 
Vol. 49 No. 2, 2021: 59-69

http://dx.doi.org/10.17159/2413-3221/2021/v49n2a12801

(License: CC BY 4.0)

The basic cations concentrations of the soils were also generally low, and so were $\mathrm{Zn}$ and $\mathrm{Mn}$, the only micronutrients analysed (Table 1). The concentrations of the basic cations were lower, but the concentrations of the micronutrients $\mathrm{Zn}$ and Mn were higher in MLV compared to the Manguzi soils (Table 1), which probably reflected differences in the management of the soils in the two areas.

TABLE 1: Variations in soil pH, P, K, Ca, Mg, Mn and $\mathrm{Zn}$ levels down the soil profile at five sites in MLV and six sites in Manguzi.

\begin{tabular}{|c|c|c|c|c|c|c|c|c|}
\hline \multirow[t]{2}{*}{ Sampling Sites } & \multirow{2}{*}{$\begin{array}{l}\text { Soil depth } \\
(\mathrm{cm})\end{array}$} & \multirow{2}{*}{$\begin{array}{l}\text { Soil pH } \\
(\mathrm{KCl} \\
\text { scale })\end{array}$} & $\mathrm{P}$ & $\mathrm{K}$ & $\mathrm{Ca}$ & $\mathrm{Mg}$ & $\mathrm{Mn}$ & $\mathrm{Zn}$ \\
\hline & & & \multicolumn{6}{|c|}{$\left(\mathrm{mg} \mathrm{kg}^{-1}\right)$} \\
\hline & \multicolumn{8}{|c|}{ Mpumalanga lowveld sites } \\
\hline \multirow[t]{4}{*}{ MLACF } & $0-10$ & 4.3 & 41.2 & 106.2 & 445 & 96.7 & 4.2 & 26.1 \\
\hline & $10-40$ & 5.4 & 30 & 78.6 & 408 & 106.2 & 2.4 & 20.7 \\
\hline & $40-60$ & 5.2 & 13.2 & 73.6 & 409 & 104 & 1.4 & 3.4 \\
\hline & Site mean & 5.0 & 28.1 & 86.1 & 420.7 & 102.2 & 2.7 & 16.7 \\
\hline \multirow{4}{*}{$\begin{array}{l}\text { Malekutu } \\
\text { Site mean }\end{array}$} & $0-10$ & 5.0 & 23 & 72 & 238 & 43 & 6.3 & 4.4 \\
\hline & $10-40$ & 5.2 & 27.2 & 76 & 308 & 69 & 4.3 & 3.8 \\
\hline & $40-60$ & 4.5 & 5.7 & 78 & 232 & 69 & 5.3 & 0.5 \\
\hline & Site mean & 4.9 & 18.6 & 75.3 & 259.3 & 60.3 & 5.3 & 2.9 \\
\hline \multirow[t]{4}{*}{ Numbi } & $0-10$ & 4.7 & 29.5 & 107 & 287 & 54 & 8.5 & 7.2 \\
\hline & $10-40$ & 4.8 & 27.3 & 81.7 & 342 & 67.7 & 5.7 & 10.6 \\
\hline & $40-60$ & 4.5 & 19.7 & 108.3 & 356 & 68.3 & 7 & 1.5 \\
\hline & Site mean & 4.7 & 25.5 & 99.0 & 328.3 & 63.2 & 7 & 6.4 \\
\hline \multirow[t]{4}{*}{ Luphisa } & $0-10$ & 6.3 & 44.5 & 62 & 325 & 69.5 & 4 & 9.7 \\
\hline & $10-40$ & 6.4 & 60 & 76 & 326 & 79.5 & 3 & 10.2 \\
\hline & $40-60$ & 6.2 & 77 & 256 & 330 & 136 & 2 & 1.9 \\
\hline & Site mean & 6.3 & 60.1 & 131.3 & 327.0 & 95.0 & 3 & 7.3 \\
\hline \multirow[t]{5}{*}{ Masoyi } & $0-10$ & 4.5 & 2 & 22 & 136 & 28 & 24 & 0.4 \\
\hline & $10-40$ & 4.3 & 4 & 52 & 168 & 46 & 4.5 & 0.8 \\
\hline & $40-60$ & 4.8 & 7 & 83 & 309 & 116 & 5 & 0.4 \\
\hline & Site mean & 4.5 & 4.3 & 52.3 & 204.3 & 63.3 & 11.2 & 0.5 \\
\hline & & \multicolumn{7}{|c|}{ Manguzi sites } \\
\hline \multirow[t]{4}{*}{ KwaMazambane } & $0-10$ & 5.1 & 15.7 & 167 & 1218 & 156 & 8 & 3.4 \\
\hline & $10-40$ & 4.8 & 9 & 86 & 443 & 104 & 3.3 & 1.0 \\
\hline & $40-60$ & 4.5 & 9.7 & 119 & 485 & 124 & 5 & 2.7 \\
\hline & Site mean & 4.8 & 11.5 & 124 & 715 & 128 & 5.4 & 2.4 \\
\hline \multirow[t]{4}{*}{ Ekuhluphekeni } & $0-10$ & 5.3 & 13.7 & 200 & 560 & 166 & 6.3 & 2.4 \\
\hline & $10-40$ & 4.7 & 12.7 & 188 & 348 & 110 & 3.3 & 2.8 \\
\hline & $40-60$ & 4.6 & 12.7 & 140 & 247 & 90 & 5 & 2.8 \\
\hline & Site mean & 4.9 & 13.0 & 176 & 385 & 122 & 4.9 & 2.7 \\
\hline
\end{tabular}


Vol. 49 No. 2, 2021: 59-69

\begin{tabular}{|l|l|l|l|l|l|l|l|l|}
\hline \multirow{5}{*}{ Thandizwe } & $0-10$ & 5.1 & 12 & 154 & 1277 & 155 & 12 & 4.3 \\
\cline { 2 - 9 } & $10-40$ & 4.8 & 7 & 72 & 481 & 108 & 3 & 1.1 \\
\cline { 2 - 9 } & $40-60$ & 4.5 & 6 & 100 & 497 & 128 & 4.7 & 1.0 \\
\cline { 2 - 9 } & Site mean & $\mathbf{4 . 8}$ & $\mathbf{8 . 3}$ & $\mathbf{1 0 8 . 7}$ & $\mathbf{7 5 1 . 7}$ & $\mathbf{1 3 0}$ & $\mathbf{6 . 6}$ & $\mathbf{2 . 1}$ \\
\hline \multirow{5}{*}{ Nsukumbili } & $0-10$ & 5.2 & 5.7 & 168 & 396 & 120 & 4.3 & 3.0 \\
\cline { 2 - 9 } & $10-40$ & 4.5 & 4 & 131 & 309 & 118 & 2.7 & 1.7 \\
\cline { 2 - 9 } & $40-60$ & 4.3 & 9.3 & 123 & 282 & 70 & 3.7 & 2 \\
\cline { 2 - 9 } & Site mean & $\mathbf{4 . 7}$ & $\mathbf{6 . 3}$ & $\mathbf{1 4 0 . 7}$ & $\mathbf{3 2 9}$ & $\mathbf{1 0 2 . 7}$ & $\mathbf{3 . 6}$ & $\mathbf{2 . 2}$ \\
\hline \multirow{5}{*}{ Ndlondlweni } & $0-10$ & 4.8 & 8 & 126 & 1007 & 144 & 14.3 & 2.7 \\
\cline { 2 - 9 } & $10-40$ & 4.6 & 5.7 & 74 & 347 & 83 & 3.7 & 1.1 \\
\cline { 2 - 9 } & $40-60$ & 4.4 & 7 & 94 & 465 & 110 & 3.3 & 0.8 \\
\cline { 2 - 9 } & Site mean & $\mathbf{4 . 6}$ & $\mathbf{6 . 9}$ & $\mathbf{9 8}$ & $\mathbf{6 0 6}$ & $\mathbf{1 1 2}$ & $\mathbf{7 . 1}$ & $\mathbf{1 . 5}$ \\
\hline \multirow{5}{*}{ Mabhudu } & $0-10$ & 5.4 & 4 & 187 & 406 & 111 & 3.3 & 0.7 \\
\cline { 2 - 9 } & $10-40$ & 4.3 & 2.3 & 100 & 173 & 91 & 1.3 & 0.6 \\
\cline { 2 - 8 } & $40-60$ & 4.3 & 4 & 84 & 252 & 73 & 2.3 & 0.7 \\
\cline { 2 - 8 } & Site mean & $\mathbf{4 . 7}$ & $\mathbf{3 . 4}$ & $\mathbf{1 2 3 . 7}$ & $\mathbf{2 7 7}$ & $\mathbf{9 1 . 7}$ & $\mathbf{2 . 3}$ & $\mathbf{0 . 7}$ \\
\hline
\end{tabular}

Any consideration of soil fertility for groundnut production has to take into account the stratified distribution of $\mathrm{Ca}, \mathrm{Mg}, \mathrm{K}$ and $\mathrm{Zn}$ down the soil profile. This is because the availability of these nutrients in the different soil layers of the soil profile affects the productivity of groundnut differently (Wolt and Adam, 1979, Zharare et al., 1993; Zharare, Blamey \& Asher, 2009; Zharare, Asher \& Blamey, 2011; Kumar et al., 2019). Because of the development of its fruit underground, groundnut has, on the one hand, relatively high demand for $\mathrm{Ca}$ in the pegzone for successful pod development compared with that required in the root zone for its vegetative growth (Wolt and Adam, 1979; Cox et al., 1982; Zharare, Blamey \& Asher, 2009; Zharare, Asher \& Blamey, 2009). On the other hand, the soil Mg and $\mathrm{K}$ concentrations in the root-zone should be relatively low to minimize the inhibition of these nutrients on pod $\mathrm{Ca}$ uptake from the peg-zone (Brady and Colwell 1945; Zharare, Asher \& Blamey, 2011). When they are in excess of $\mathrm{Ca}$ in the peg-zone, pop production increases (Brady and Colwell 1945; Cox et al., 1982). In the current study, peg-zone Ca concentration ranged from 136 to $445 \mathrm{mg}$ $\mathrm{kg}^{-1}$ of soil in MLV and from 173 to $1218 \mathrm{mg} \mathrm{kg}^{-1}$ in Manguzi (Table 1). These values were above $100 \mathrm{mg} \mathrm{kg}^{-1}$ of soil Ca level considered adequate for proper groundnut pod development in South Africa (Swanevelder, 1998). Hartzog and Adams (1973) also reported that a soil Ca concentration of $100 \mathrm{mg} \mathrm{kg}^{-1}$ was regarded as sufficient for groundnut production for the runner type groundnut, and there was no need for gypsum application, but soils with Ca concentration below $87.5 \mathrm{mg} \mathrm{kg}^{-1}$ needed gypsum application. With the current study, there are no sites falling below $87.5 \mathrm{mg} \mathrm{kg}^{-1}$ (Table 1). Thus, gypsum application is not necessary in these soils, especially for Valencia and Spanish types of groundnut, which require less $\mathrm{Ca}$ in the peg-zone than do Virginia groundnut (Cox et al., 1982). However, since there is a need to apply lime in both locations, its application will add more $\mathrm{Ca}$ to the soil. 
Wolt and Adams (1979) determined that 0.25 is the critical $\mathrm{Ca}:(\mathrm{Ca}+\mathrm{Mg}+\mathrm{K})$ ratio for maximising pod filling while only a ratio of 0.1 was required for maximizing vegetative growth of groundnut. In the present study, the $\mathrm{Ca} /(\mathrm{Ca}+\mathrm{Mg}+\mathrm{K})$ ratios in the peg- and root zones were above 0.60 at all the sites tested, with a majority of the sites falling in the range of 0.7 to 0.9 (Table 2). Thus, the ratios were substantially above the critical values for maximal pod filling and vegetative growth, which further confirmed that Ca deficiency is not anticipated to limit groundnut yields in both Manguzi and MLV. As for the other macro-nutrients nutrients analysed; generally, 40 to $88 \mathrm{mg} \mathrm{kg}^{-1}$ of $\mathrm{K}$ (Hanlon, Kidder \& Mcneal, 1990), 10 to $30 \mathrm{mg} \mathrm{kg}^{-}$ ${ }^{1}$ of $\mathrm{Mg}$ (Hodges, Gascho \& Kidder 1994) and 8 to $10 \mathrm{mg} \mathrm{kg}^{-1}$ of P (Singh, Basu \& Singh, 2004) in the soil are considered adequate for healthy vegetative growth of groundnut. In the current study, the root zone concentrations of $\mathrm{Mg}$ ranged from 46 to $106.2 \mathrm{mg} / \mathrm{kg}, \mathrm{K}$ ranged from 52 to $81.7 \mathrm{mg} / \mathrm{kg}$, and P ranged from 4 to $30 \mathrm{mg} / \mathrm{kg}$ in MLV. In Manguzi, the soil concentrations of $\mathrm{Mg}$ ranged from 83 to $118 \mathrm{mg} / \mathrm{kg}, \mathrm{K}$ from 72 to $188 \mathrm{mg} / \mathrm{kg}$ and $\mathrm{P}$ from 2.3 to $12.7 \mathrm{mg} / \mathrm{kg}$. From these data, $\mathrm{K}$ was marginally sufficient, while $\mathrm{P}$ was either marginally sufficient or lower than the optimal range for groundnut. Based on the data, both Manguzi and MPLV soils require an application of $\mathrm{K}$ at a rate of between 25 and $45 \mathrm{~kg} \mathrm{~K} 2 \mathrm{O} \mathrm{ha}{ }^{-1}$ (Singh, Basu \& Singh, 2004), with the higher rate being recommended for MPLV, which has lower sufficient $\mathrm{K}$ levels (Table 1).

The deficiency of $\mathrm{P}$ was severe in Manguzi soils, whereas in MLV, the P levels were largely adequate by a high margin compared to the index levels ( 8 to $10 \mathrm{mg} \mathrm{kg}^{-1}$ ) for healthy growth of groundnut, except at Masoyi. However, because of the acidic nature of the soils, the availability of $\mathrm{P}$ could be low due to fixation by iron (Fe) and aluminium (Al) oxides (Penn and Camberato, 2019). Liming the soil to between 5.5 and 6.5 will release $\mathrm{P}$ from fixation, making it more available to plants. Care is, however, needed not to over lime the soils as it would cause precipitation of $\mathrm{P}$ by $\mathrm{Ca}$, thus making it unavailable to plants (Penn and Camberato, 2019). In the absence of a soil test, groundnut production in Manguzi could benefit from an application of 30-40 $\mathrm{kg} \mathrm{P}_{2} \mathrm{O}_{5} \mathrm{ha}^{-1}$ (Singh, Basu \& Singh, 2004), whereas the soil in MPLV requires lower $\mathrm{P}$ application rates for maintenance. It is best to apply $\mathrm{P}$ as a broadcast basal application at planting. However, if there is no sufficient amount for broadcasting, it can be dolloped in the planting hole below the seed but not in contact with the seed. This will also reduce the fixation of $\mathrm{P}$ by the soil compared to broadcasting.

Magnesium tended to be more in the peg-zone than in the root-zone and subsoil at Manguzi, but in MLV, the Mg concentration was higher in the root-zone. The higher Mg concentration in the peg-zone in Manguzi might negatively affect the development of the pods since $\mathrm{Mg}$ suppresses $\mathrm{Ca}$ and $\mathrm{Zn}$ uptake by groundnut pod from the peg-zone (Zharare et al., 1993; Zharare, Asher \& Blamey, 2011), and both of these nutrients are required in the peg-zone for proper pod development (Zharare et al., 1993). Furthermore, the omission of Mg in the pod culture solution was shown by Zharare et al. (1993) to improve groundnut pod and seed development. 
Hence, the need to carefully balance the $\mathrm{Ca}, \mathrm{Zn}$ and $\mathrm{Mg}$ nutrition of groundnut in the peg-zone. Therefore, when correcting the low soil $\mathrm{pH}$ in both MLV and Manguzi, it would be advisable to use calcitic lime with no $\mathrm{Mg}$ rather than dolomitic lime, which contains $\mathrm{Mg}$, since the soils have adequate $\mathrm{Mg}$.

Although groundnut requires $\mathrm{Zn}$ in the peg-zone for pod development (Zharare et al., 1993), the concentration required in the peg-zone to satisfy the requirements for pod development has not yet been determined. Nonetheless, groundnut is said to require about $0.5 \mathrm{mg} \mathrm{kg}^{-1}$ to $1.0 \mathrm{mg}$ $\mathrm{Zn} \mathrm{kg}^{-1}$ of soil (Hanlon, Kidder \& Mcneal, 1990, Plank. 1989). In the present study, the Zn level in the peg-zone varied from 0.4 to $26.1 \mathrm{mg} \mathrm{kg}^{-1}$ in MLV and 0.7 to $4.3 \mathrm{mg} \mathrm{kg}^{-1}$ in Manguzi. In the root zone, the levels of $\mathrm{Zn}$ ranged from 0.6 to $2.8 \mathrm{mg} \mathrm{kg}^{-1}$ in Manguzi. With the exception of one site (MLVACF) in MLV, the levels are substantially higher than the critical soil Zn level ( 0.5 to $1.0 \mathrm{mg} \mathrm{kg-1} \mathrm{soil)} \mathrm{required} \mathrm{for} \mathrm{optimal} \mathrm{groundnut} \mathrm{production} \mathrm{under} \mathrm{soil} \mathrm{pH} 5.5$ to 7.0. Therefore, substantial groundnut yield suppression from $\mathrm{Zn}$ deficiency is not expected in both MLV and Manguzi. However, liming the soils to correct the low $\mathrm{pH}$ generally prevalent in these soils is expected to induce $\mathrm{Zn}$ deficiency at some of the sites with low $\mathrm{Zn}$ concentration as both high pH (Fageria and Zimmermann, 1998) and Ca (Baker 1978) suppress Zn uptake by plants. Consequently, it might be prudent to apply between 2-4 $\mathrm{kg} \mathrm{Zn} \mathrm{ha}^{-1}$ as $\mathrm{ZnSO} 4$ or equivalent as $\mathrm{ZnO}$ (Singh et al., 2004) to accompany liming in order to offset yield losses through $\mathrm{pH}$ - and $\mathrm{Ca}$-induced $\mathrm{Zn}$ deficiency, especially when large amounts of lime are applied.

TABLE 2: The Ca: $(\mathrm{Ca}+\mathrm{Mg}+\mathrm{K})$ concentration ratios in the $0-10 \mathrm{~cm}$ soil depth and 10-40 cm soil depth at 6 sites in Manguzi and 5 sites in MLV.

\begin{tabular}{|c|c|c|c|c|c|}
\hline $\begin{array}{l}\text { Sampling sites in } \\
\text { Manguzi (NCP } \\
\text { of KZN) }\end{array}$ & $\begin{array}{l}\text { Soil } \\
\text { depth } \\
(\mathrm{cm}) \\
\end{array}$ & $\begin{array}{l}\mathrm{Ca}:(\mathrm{Ca}+\mathrm{Mg}+ \\
\mathrm{K}) \text { Ratio }\end{array}$ & $\begin{array}{l}\text { Sampling } \\
\text { sites in } \\
\text { MLV }\end{array}$ & $\begin{array}{l}\text { Soil } \\
\text { depth } \\
(\mathrm{cm}) \\
\end{array}$ & $\begin{array}{l}\mathrm{Ca}:(\mathrm{Ca}+\mathrm{Mg}+ \\
\mathrm{K}) \text { Ratio }\end{array}$ \\
\hline \multirow[t]{2}{*}{ KwaMazambane } & $0-10$ & 0.89 & \multirow[t]{2}{*}{ LVACF } & $0-10$ & 0.82 \\
\hline & $10-40$ & 0.81 & & $10-40$ & 0.79 \\
\hline \multirow{2}{*}{ Ekuhluphekeni } & $0-10$ & 0.77 & \multirow{2}{*}{ Malekutu } & $0-10$ & 0.85 \\
\hline & $10-40$ & 0.76 & & $10-40$ & 0.82 \\
\hline \multirow{2}{*}{ Thandizwe } & $0-10$ & 0.89 & \multirow{2}{*}{ Numbi } & $0-10$ & 0.84 \\
\hline & $10-40$ & 0.82 & & $10-40$ & 0.83 \\
\hline \multirow{2}{*}{ Nsukumbili } & $0-10$ & 0.77 & \multirow{2}{*}{ Luphisa } & $0-10$ & 0.82 \\
\hline & $10-40$ & 0.72 & & $10-40$ & 0.80 \\
\hline \multirow{2}{*}{ Ndlondlweni } & $0-10$ & 0.87 & \multirow{2}{*}{ Masoyi } & $0-10$ & 0.83 \\
\hline & $10-40$ & 0.81 & & $10-40$ & 0.79 \\
\hline \multirow{2}{*}{ Mabhudu } & $0-10$ & 0.79 & & & \\
\hline & $10-40$ & 0.66 & & & \\
\hline
\end{tabular}


Generally, Mn toxicity is the main problem encountered in acid sandy soils with $\mathrm{pH}$ values in the range of 4.5 to 5.0 because of its high solubility under acidic conditions. However, even though the soils in MLV and Manguzi are acidic, the soil Mn concentrations ranging from 4 to $24 \mathrm{mg} \mathrm{kg}^{-1}$ in MLV and from 3 to $14 \mathrm{mg} \mathrm{kg}-1$ in Manguzi are too low to cause toxicity in groundnut. Rather, Mn deficiency might be expected in both locations. The critical soil Mn concentration for groundnut is 3 to $7 \mathrm{mg} \mathrm{kg}^{-1}$ in soil with a $\mathrm{pH}$ between 5.5 and 7.0 (Hanlon, Kidder \& Mcneal,1990; Plank, 1989). This range is similar to the mean site range 2.3 to 7.1 $\mathrm{mg} \mathrm{kg}^{-1}$ obtained in the acidic soil in MLV and Manguzi, except for Masoyi in MLV, which had a mean Mn concentration of $11.2 \mathrm{mg} \mathrm{kg}^{-1}$. Manganese solubility and availability to plants decrease with increasing soil $\mathrm{pH}$. Thus, raising the soil $\mathrm{pH}$ above 5.5 will exacerbate $\mathrm{Mn}$ deficiency on these soils. Consequently, it will be necessary to also apply Mn when liming the soils. In the absence of a soil test, an application from 1 to $4 \mathrm{~kg} \mathrm{Mn} \mathrm{ha}^{-1}$ as $\mathrm{MnSO}_{4}, \mathrm{MnO}_{2}$, $\mathrm{MnCO}_{3}$, or $\mathrm{MnCl}_{2}$ (Sing et al., 2004) is herein recommended along with fertilizer depending on the amount of lime applied.

\section{CONCLUSIONS AND RECOMMENDATIONS}

The sandy soils on which groundnut is being grown by smallholder farmers in MPLV and Manguzi were found to be acidic and low in $\mathrm{Ca}, \mathrm{Mg}, \mathrm{K}, \mathrm{P}, \mathrm{Zn}$ and $\mathrm{Mn}$ concentrations. However, $\mathrm{Ca}, \mathrm{Mg}$ and $\mathrm{K}$ were present in concentrations that are adequate for groundnut production. Therefore, the soils do not need the application of these nutrients apart from maintenance dressings. The $\mathrm{P}$ and $\mathrm{Mn}$ concentrations were in the deficient ranges, and the soil $\mathrm{Zn}$ concentration was marginal for groundnut. Thus, $\mathrm{P}, \mathrm{Mn}$ and $\mathrm{Zn}$ could limit groundnut yields in MPLV and Manguzi. To optimize groundnut productivity on these acidic soils, lime should be applied at low rates of 200 to $500 \mathrm{~kg} / \mathrm{ha}$. This should be done with calcitic lime accompanied with applications of $\mathrm{P}, \mathrm{Mn}$ and $\mathrm{Zn}$ to prevent lime-exacerbated deficiencies of these nutrients.

\section{ACKNOWLEDGEMENT}

The authors would like to Acknowledge the National Research Foundation and the University of Zululand for supporting this research.

\section{REFERENCES}

ARYA, S. S., SALVE, A. R. \& CHAUHAN, S. 2016. Peanuts as functional food: a review. J. Food Sci. Technol., 53(1):31-41; https://doi.org/10.1007/s13197-015-2007-9.

BAKER, A.J.M., 1978. The uptake of zinc and calcium from solution culture by zinc tolerant and non tolerant Silene maritima WITH. in relation to calcium supply. New Phytol., 81:321-330.

BRADY, N.C. \& COLWELL, W.E. 1945. Yield and quality of large-seeded type peanuts as affected by potassium and certain combinations of potassium, magnesium and calcium. $J$. Am. Soc. Agron., 37:429-42. 
COX, F.R., ADAMS, F., BILLY, B. \& TUCKER, B. 1982. Liming, fertilization, and mineral nutrition. In H.H. Pettee \& C.T. Young, eds. Peanut Science and Technology. Yoakum, TX. American Peanut Research and Education Society Inc. pp. 139-164.

FAGERIA, N.K. \& ZIMMERMANN, F.J.P. 1998. Influence of pH on growth and nutrient uptake by crop species in an oxisol. Commun. Soil Sci. Plan., 29(17-18):2675-2682: https://doi.org/10.1080/00103629809370142

GRUNDLING, A.T. 2011. Traditional water sources - Lifeline in a time of need. Water Wheel, 10(5): 36-39.

HANLON, E.A., KIDDER, G. \& MCNEAL, B.L. 1990. Soil, container media, and water testing: Interpretations and institute for food and agricultural society standardized fertilization recommendations. Florida co-operatives extension and services, Circuilar 817. Gainesville: Institute of Food and Agricultural Sciences, University of Florida,. Service,

HARTZOG, D.L. \& ADAMS, F. 1973. Fertilizer, gypsum, and lime experiments with peanuts in Alabama. Alabama Agricultural Experimental Station Bulletin, Alabama: Auburn University.

HODGES, S.C., GASCHO, G.S. \& KIDDER, G. 1994. Chapter 6: Calcium and Magnesium. In C.C. Mitchell ed. Research-based soil testing interpretation and fertilizer recommendation for peanuts on Coastal Plain soils. Southern Cooperative series bulletin No.380. Alabama: Auburn University.

HUNTER, A.H. 1974. Tentative ISFEI extraction procedure. International Soil Fertility Evaluation and Improvement Project. Raleigh, USA; North Carolina State University.

JANILA P., NIGAM, S.N., MANISH, K.P., NAGESH, P., \& VARSHNEY, R.K., 2013. Groundnut improvement use of genetic and genomic tools. J Plant Soil, 4:1-16.

KUMAR, R., PANDEY, M.K., CHOUDHRY, S.R., NAYYAR, H., KEPINSKI, S. \& VARSHNEY, R.K., 2019. Peg biology: Deciphering the molecular regulations involved during peanut peg development. Front. Plant Sci., 10:1289: https://doi.org/10.3389/fpls.2019.01289

LENGWATI, D.M., MATHEWS, C. \& Dakora F.D. 2020. Rotation Benefits From N2-Fixing Grain Legumes to Cereals: From Increases in Seed Yield and Quality to Greater Household Cash-Income by a Following Maize Crop. Front. Sustain. Food Syst. 4:94. doi: 10.3389/fsufs.2020.00094

MACCIO, D., FABRA, A. \& CASTRO, S. 2002. Acidity and calcium interaction affect the growth of bradyrhizobium sp and the attachment to peanut roots. Soil Biol. Biochem., 34: 201-208.

MATHEWS, C. 2010. An overview of indigenous crop development by the Mpumalanga Department of Agriculture and Land Administration. S. Afr. J. Plant Soil, 27(4):337-340.

MATTHEWS, W.S. 2007. Contributions to the ecology of Maputaland, southern Africa, with emphasis on Sand Forest. PhD thesis. Department of Botany, University of Pretoria, Pretoria.

MEHLICH, A. 1984. Mehlich 3 soil test extractant: A modification of Mehlich 2 extractant. Commun. Soil Sci. Plan., 15(12):1409-1416.. 
MUCINA, L., \& RUTHERFORD, M.C. 2006. The vegetation of South Africa, Lesotho and Swaziland. Strelitzia 19. South Africa National Biodiversity Institute, Pretoria.

MURATA, M.R., ZHARARE. G.E. \& HAMMES, P.S., 2013. Interactions of podzone ph and calcium concentration on fructification of groundnut grown in solution culture. J. Plant Nutr., 36(1):32-41.

NCUBE, E., FLETT, B.C., WAALWIJK, C. \& VILJOEN, A. 2010. Occurrence of aflatoxins and aflatoxin-producing Aspergillus spp. associated with groundnut production in subsistence farming systems in South Africa. S. Afr. J. Plant Soil, 7:195-198.

PANSU, M. \& GAUTHEYROU, J. 2006. Handbook of soil analysis: mineralogical Organic and Inorganic Methods. Berlin, Heidelberg, New York: Springer.

PATERSON, D.G. 2012. Soils and Agricultural Potential for the Proposed P166 road near Mbombela, Mpumalanga Province. Report no. GW/A/2012/48.

PENN, C.J., \& CAMBERATO, J.J. 2019. Critical review on soil chemical processes that control how soil pH affects phosphorus availability to plants. Agriculture, 9(6): 120; https://doi.org/10.3390/agriculture9060120.

PHOKANE, S., FLETT, B.C., NCUBE, E. \& RHEEDER, J.P. \& ROSE, L.J. 2019. Agricultural practices and their potential role in mycotoxin contamination of maize and groundnut subsistence farming. S. Afr. J. Sci., 115(9/10)://doi. org/10.17159/sajs.2019/6221

PLANK, C.O. 1989. Plant analysis handbook for Georgia. Atherns: University of Georgia.

RAMJEAWON, M., DEMLIE, M. TOUCHER, M. L. \& VAN RENSBURG S. J. 2020. Analysis of three decades of land cover changes in the Maputaland Coastal Plain, South Africa. Koedoe | Vol 62, No 1 | a1642 |DOI: https://doi.org/10.4102/koedoe.v62i1.1642| ROY, RN, FINCK, A, BLAIR, GJ \& TANDON, H.L.S. 2006. Plant nutrition for food security. A guide for integrated nutrient management. FAO Fertilizer and Plant Nutrition Bulletin 16, Rome: Food and Agriculture Organization of the United Nations.

SINGH, A.L., BASU, M. S. \& SINGH, N.B. 2004. Mineral disorders of groundnut. Junagadh: Indian Council of Agricultural Research

SWANEVELDER, C.J., 1998. Groundnuts- always tops. Potchefstroom, South Africa, ARCGrain Crops Institute.

WOLT, J.D. \& ADAMS, F. 1979. Critical levels of soil and nutrient solution calcium for vegetative growth and fruit development of florunner peanuts. Soil Sci. Soc. Am. J., 43:1159-1164.

ZHARARE, G.E., ASHER, C.J., BLAMEY, F.P.C. \& DART, P.J. 1993. Pod development of groundnut (Arachis hypogaea L.) in solution culture. Plant Soil, 156:55-358.

ZHARARE, G.E., ASHER, C.J. \& BLAMEY, F.P.C. 2011. Magnesium antagonizes peg-zone calcium and zinc uptake by developing peanut pods. J. Plant Nutr., 34:1-11.

ZHARARE, G.E., BLAMEY F.P.C., \& ASHER, C.J. 2009. Calcium nutrition of Peanut (Arachis hypogaea L.) grown in solution culture. II. Peg-zone and tissue calcium requirements for fruiting of a Virginia and a Spanish peanut. J. Plant Nutr., 32:1843-1860. 
S. Afr. J. Agric. Ext.

Zharare \& Vilane Vol. 49 No. 2, 2021: 59-69

http://dx.doi.org/10.17159/2413-3221/2021/v49n2a12801

(License: CC BY 4.0)

ZHARARE, G. E., ASHER, C. J., \& BLAMEY, F. P. C. 2009. Calcium nutrition of peanut grown in solution culture. I. Genetic variation in Ca requirements for vegetative growth. J. Plant Nutr., 32:1831-1842. 